\section{La política bonaerense mirada \\ desde Bahía Blanca. LA NUEVA PROVINCIA \\ ante la respuesta conservadora al desafío \\ de la democratización, 1912-1913 \\ Laura Llull}

Este trabajo forma parte de la tesis doctoral de la autora:

Laura Llull es Docente del Área Americana y Argentina, Departamento de Humanidades, Universidad Nacional del Sur.

E-mail: Illull@infovia.com.ar

\section{Resumen}

Tras la sanción de la ley Sáenz Peña, la dirigencia conservadora de Buenos Aires se vio ante el desafío de modernizar las prácticas políticas de la provincia. Los sectores reformistas de dicha dirigencia, que buscaban modificar la legislación electoral para legitimar su hegemonía gubernamental, vieron concretadas sus aspiraciones en la reforma de la legislación electoral bonaerense en 1913, bajo la administración del doctor Eduardo Arana.

Los periódicos que integraban el campo periodístico de la ciudad de Bahía Blanca siguieron con interés las alternativas de este proceso.

Este artículo intenta acceder a la compleja trama de argumentaciones que uno de ellos, el matutino La Nueva Provincia fue construyendo, fundamentalmente desde sus espacios editoriales, al centrar sus reflexiones en las alternativas de este proceso de modernización de la política bonaerense en el período 1912-1913.
"En búsqueda de la cultura política de un periódico bahienSe: LA NUEVA PROVINCIA.1916-1930», bajo la dirección de la Dra. Mabel Cernadas de Bulnes.

\section{Summary}

After the sanction of the "law Sáenz Peña», the Conservative Party of Buenos Aires had to confront an important challenge: to modernize the political practices of this province. The reformist leaders of the party wanted to modify the electoral legislation in order to legitimize their governmental hegemony. Their aspirations led to an electoral legislation reform in 1913, under doctor Eduardo Arana's administration.

The newspapers that integrated the journalistic field of Bahía Blanca city followed closely the alternatives of this process. This article focuses its attention on La Nueva Provincia's editorial reflections about this period and also shows its relation with the political strategies of the Radical Party of Buenos Aires during the period 1912-1913. 